\title{
Correction to: Polycratic hierarchies and networks: what simulation-modeling at the LHC can teach us about the epistemology of simulation
}

\author{
Florian J. Boge ${ }^{1,2}$ D Christian Zeitnitz ${ }^{2,3}$
}

Published online: 18 June 2021

(c) Springer Nature B.V. 2021

\section{Correction to: Synthese https://doi.org/10.1007/s11229-020-02667-3}

The article Polycratic hierarchies and networks: what simulation-modeling at the LHC can teach us about the epistemology of simulation, written by Florian J. Boge and Christian Zeitnitz, was originally published electronically on the publisher's internet portal on 14 May 2021 without open access. With the author(s)' decision to opt for Open Choice the copyright of the article changed on 26 May 2021 to $\odot$ The Author(s) 2021 and the article is forthwith distributed under a Creative Commons Attribution.

This article is licensed under a Creative Commons Attribution 4.0 International License, which permits use, sharing, adaptation, distribution and reproduction in any medium or format, as long as you give appropriate credit to the original author(s) and the source, provide a link to the Creative Commons licence, and indicate if changes were made.

The images or other third party material in this article are included in the article's Creative Commons licence, unless indicated otherwise in a credit line to the material. If material is not included in the article's Creative Commons licence and your intended use is not permitted by statutory regulation or exceeds the permitted use, you will need to obtain permission directly from the copyright holder.

To view a copy of this licence, visit http://creativecommons.org/licenses/by/4.0/.

The original article can be found online at https://doi.org/10.1007/s11229-020-02667-3.

Florian J. Boge

fjboge@uni-wuppertal.de

1 Institute for Theoretical Particle Physics and Cosmology, RWTH Aachen University, Aachen, Germany

2 Interdisciplinary Centre for Science and Technology Studies (IZWT), Bergische Universität Wuppertal, Gaußstr. 20, 42119 Wuppertal, Germany

3 Physics Department, Bergische Universität Wuppertal, Wuppertal, Germany 
Publisher's Note Springer Nature remains neutral with regard to jurisdictional claims in published maps and institutional affiliations. 